\title{
PENTINGNYA PEMBUKUAN SEDERHANA BAGI KELOMPOK UMKM KUB MURAKABI DESA NGARGOYOSO
}

\author{
Cahyani Tunggal Sari, Etty Indriani \\ Manajemen, STIE AUB Surakarta \\ E-mail: cahyani031084@gmail.com
}

\begin{abstract}
Joint Business Group MURAKABI is one of the existing business groups in Ngargoyoso Karanganyar District. This Joint Business Group produces various processed foods with purple yams. Products produced include thymus and bakpia. KUB Murakabi is an initiative of Bu Endang as chairman of UMKM to empower mothers in Ngargoyoso region. Initially $\mathrm{Bu}$ Endang participated in catering training from the Department of Cooperatives and MSMEs later, the science of the training obtained, transmitted to mothers in the region Ngargoyoso. The mothers who joined in the joint business group Murakabi mostly are housewives and farmers. The activity of cultivating purple sweet potato into bakpia and thymus is done at night because in the morning, thymus and bakpia products are taken by traders. The marketing system is still simple because production is done only if there is an order. And sales only with the breaking system, do not serve the consignment system. Financial records are still very simple, that is only recorded expenses and income, there are no posts in accordance with the department either production, marketing, and human resources. Training activities are for all human resources involved in Joint Tasks Group Murakabi. The proposer proposes a simple bookkeeping theme of UMKM in line with the study program which oversees the proposer of management study program. In addition, MSME's simple bookkeeping training program is also in line with government programs that expect SMEs to go to class.
\end{abstract}

Keywords: simple bookkeeping, MSME, KUB Murakabi Ngargoyoso Village

\section{ABSTRAK}

Kelompok Usaha Bersama MURAKABI merupakan salah satu kelompok usaha yang ada di Ngargoyoso Kabupaten Karanganyar. Kelompok Usaha Bersama ini memproduksi aneka makanan olahan dengan bahan ubi ungu. Produk yang dihasilkan antara lain timus dan bakpia. KUB Murakabi ini merupakan inisiatif dari Bu Endang selaku ketua UMKM untuk memberdayakan ibu-ibu yang ada di wilayah Ngargoyoso. Awalnya Bu Endang mengikuti pelatihan boga dari Dinas Koperasi dan UMKM kemudian, ilmu dari pelatihan yang didapat, ditularkan kepada ibu-ibu di wilayah Ngargoyoso. Ibu-ibu yang tergabung dalam kelompok usaha bersama Murakabi sebagian besar adalah ibu rumah tangga dan petani. Kegiatan mengolah ubi ungu menjadi bakpia dan timus ini dilakukan di malam hari karena di pagi harinya, produk timus dan bakpia diambil oleh para pedagang. Sistem pemasarannya masih sederhana karena produksi dilakukan hanya jika ada pesanan. Dan penjualan hanya dengan sistem beli putus, tidak melayani sistem konsinyasi. Pencatatan keuangan masih sangat sederhana, yaitu hanya dicatat pengeluaran dan pemasukan, belum ada pos-pos sesuai dengan departemennya baik produksi, pemasaran, maupun sumber daya manusia. Kegiatan Pelatihan diperuntukkan bagi seluruh sumber daya manusia yang terlibat dalam Kelompok Usaha Bersama Murakabi. Pengusul mengajukan tema pembukuan sederhana UMKM sejalan dengan program studi yang menaungi pengusul yaitu program studi manajemen. Selain itu, program pelatihan pembukuan sederhana UMKM juga sejalan dengan program pemerintah yang mengharapkan UMKM naik kelas.

Kata Kunci : pembukuan sederhana, UMKM, KUB Murakabi Desa Ngargoyoso

\section{PENDAHULUAN}

Kelompok Usaha Bersama MURAKABI merupakan salah satu kelompok usaha yang ada di Ngargoyoso Kabupaten Karanganyar. Kelompok Usaha Bersama ini memproduksi aneka makanan olahan dengan bahan ubi ungu. Produk yang dihasilkan antara lain timus dan bakpia. KUB 
Murakabi ini merupakan inisiatif dari Bu Endang selaku ketua UMKM untuk memberdayakan ibu-ibu yang ada di wilayah Ngargoyoso. Awalnya Bu Endang mengikuti pelatihan boga dari Dinas Koperasi dan UMKM kemudian, ilmu dari pelatihan yang didapat, ditularkan kepada ibu-ibu di wilayah Ngargoyoso. Ibu-ibu yang tergabung dalam kelompok usaha bersama Murakabi sebagian besar adalah ibu rumah tangga dan petani. Kegiatan mengolah ubi ungu menjadi bakpia dan timus ini dilakukan di malam hari karena di pagi harinya, produk timus dan bakpia diambil oleh para pedagang. Sistem pemasarannya masih sederhana karena produksi dilakukan hanya jika ada pesanan. Dan penjualan hanya dengan sistem beli putus, tidak melayani sistem konsinyasi. Pencatatan keuangan masih sangat sederhana, yaitu hanya dicatat pengeluaran dan pemasukan, belum ada pos-pos sesuai dengan departemennya baik produksi, pemasaran, maupun sumber daya manusia. Dalam sebuah usaha, pembukuan merupakan salah satu faktor pondasi usaha yang penting. Pembukuan usaha berkaitan erat dengan progres usaha. Dengan adanya pembukuan, pelaku usaha dapat mengetahui sejauh mana perkembangan usahanya. Selain itu, pembukuan yang tepat dan jelas dapat memberikan informasi yang berguna terkait dengan permodalan usaha.

Salah satu masalah yang sering terabaikan oleh para pelaku bisnis UMKM yaitu tentang pengelolaan keuangan, termasuk yang terjadi pada UMKM di kota Surakarta. Dampak dari diabaikannya pengelolaan keuangan mungkin tidak terlihat jelas, namun tanpa metode akuntansi yang yang efektif, kemungkinan besar pengelola tidak bisa memahami bisnisnya secara utuh. Akuntansi merupakan kunci indikator kinerja sebuah usaha. Informasi yang dihasilkan oleh catatan akuntansi berguna bagi pengambilan keputusan sehingga dapat meningkatkan efektifitas pengelolaan usaha. Informasi tersebut memungkinkan para pelaku UMKM dalam mengidentifikasi dan memprediksi permasalahan keuangan yang mungkin timbul, kemudian dapat mengambil langkah yang tepat dan cepat dalam mengatasinya. Berdasarkan latar belakang diatas, maka peneliti ingin mengidentifikasi lebih lanjut faktor yang mempengaruhi persepsi dan pemahaman pelaku UMKM akan pentingnya sistem pembukuan dan laporan keuangan.

Penelitian Pinasti (2001) menemukan bahwa para pedagang kecil di pasar tradisional di kabupaten Banyumas tidak menyelenggarakan dan tidak menggunakan informasi akuntansi dalam pengelolaan usahanya. Keputusankeputusan dalam pengelolaan usaha lebih banyak didasarkan pada informasi-informasi non akuntansi dan pengamatan sepintas atas situasi pasar. Secara umum mereka menganggap informasi akuntansi tidak penting. Alasan-alasan yang dikemukakan antara lain: mereka merasa terlalu direpotkan dengan penyelenggaraan catatan akuntansi tersebut dan yang penting mereka mendapatkan laba tanpa dibebani dengan penyelenggaraan akuntansi. Mereka belum merasakan manfaat dari penyelenggaraan pembukuan. Baas dan Schrooten (2006) dalam penelitiannya menyebutkan bahwa perbankan dalam penyaluran kreditnya kepada UMKM menggunakan Soft Information \& Hard Information. Soft Information menggunakan teknik Relationship Lending yakni penyaluran kredit atas dasar kepercayaan dan hubungan yang telah terbina baik antara bank dengan pengusaha. Hard information diantaranya menggunakan: 1) Financial Statement Lending, yakni dengan menggunakan laporan keuangan yang telah sesuai dengan standar akuntansi yang berlaku sebagai sumber informasi untuk pemberian kredit, 2) Assets Based Lending yakni dengan menggunakan informasi terkait aset-aset yang dijadikan jaminan, 3) Credit Scoring, penggunaan teknik statistik dengan menggunakan data-data keuangan dari laporan keuangan dan juga creditworthiness dan latar belakang dari pemilik UMKM untuk diberikan peringkat. Baas dan Schrooten berkesimpulan bahwa hampir di seluruh dunia UMKM mengalami kesulitan dalam mendapatkan kredit perbankan. Salah satu penyebabnya adalah adanya keterbatasa informasi yang mampu diberikan oleh UMKM kepada pihak eksternal. Saran yang diberika dalam penelitian tersebut adalah pentingnya standar akuntansi yang mampu mengakomodir kebutuhan dari pengusaha UMKM, agar dapat membantu UMKM dalam menyediakan informasi keuangan yang lebih berkualitas. Cziráky et al. (2005) meneliti mengenai faktor-faktor yang menyebabkan rendahnya pemberian kredit UMKM di Kroasia. Program kredit UMKM yang dijalankan pemerintah Kroasia ternyata penyaluran kreditnya rendah, padahal pemerintah telah memberikan subsidi terhadap tingkat suku bunganya serta pasokan dana yang dianggap mencukupi kebutuhan kredit bagi 
UMKM. Hasil penelitian mereka menunjukkan bahwa rata-rata perbankan tidak konsisten dalam hal penggunaan criteria persetujuan kredit.

\section{METODE}

Sasaran dari KegiatanPengabdian Masyarakat "Pelatihan Pembukuan Sederhana UMKM Kelompok Usaha Bersama Murakabi Desa Ngargoyoso Kabupaten Karanganyar" yaitu sumber daya manusia yang tergabung dalam Kelompok Usaha Bersama Murakabi. Program pengabdian kepada masyarakat dilaksanakan berkaitan dengan pengembangan program UMKM Naik Kelas yang merupakan salah satu program pemerintah Indonesia di masa Presiden Jokowi saat ini.

Kegiatan Pengabdian Kepada Masyarakat ini berbentuk Pelatihan dan Pendampingan mengenai pembukuan sederhana kepada masyarakat Ngargoyoso dengan tujuan memberikan edukasi pentingnya proses pembukuan dan akuntansi dalam menjalankan usaha. Kegiatan ini sejalan dengan kemampuan pengusul dalam penguasaan pembukuan sederhana UMKM. Materi yang diberikan adalah pembukuan sederhana yang menuju pada pembuatan laporan keuangan sederhana yang terdiri dari laporan laba rugi, neraca, dan arus kas.

\section{HASIL, PEMBAHASAN, DAN DAMPAK}

Kegiatan pelatihan pembukuan sederhana dilaksanakan selama 5 bulan. Pelaksanaan pelatihan tentang pembukuan sederhana dilaksanakan setelah kegiatan rutinitas harian masyarakat selesai. Adapun lokasi pelaksanaan pelatihan bertempat di Balai Dusun. Peserta pelatihan terdiri atas Anggota KUB Murakabi, perangkat dusun, dan masyarakat pelaku UMKM setempat. Peserta pelatihan yang hadir dalam kegiatan pengabdian kepada masyarakat adalah 30 orang. Pada kegiatan pelatihan yang telah dilaksanakan menunjukkan antusiasme yang sangat tinggi dari peserta yang merupakan pelaku UMKM. Antusiasme tersebut ditunjukkan dengan banyaknya pertanyaan yang diajukan seputar pembukuan maupun pengelolaan dan perencanaan keuangan. Narasumber berusaha untuk menjawab pertanyaan-pertanyaan tersebut dan memberikan penjelasan yang mendalam mengenai tema yang ditanyakan.

Tim pengabdian kepada masyarakat berharap kendala-kendala yang dihadapi dalam keuangan usaha dapat dihadapi dengan proses pembukuan yang baik. Tim pengabdian juga berharap, materi yang disampaikan dapat langsung dipraktikkan dalam kondisi nyata oleh pelaku UMKM. Menurut pengamatan tim pengabdian pada masyarakat bahwa selama pelaksanaan kegiatan pelatihan tersebut nampak bahwa masyarakat pelaku UMKM di Ngargoyoso masih awam dengan pembukuan. Padahal pembukuan ini penting bagi keberlanjutan usaha maupun akses permodalan.

Materi yang disampaikan adalah tentang pembukuan sederhana dan pembuatan laporan keuangan. Metode pembuatan pembukuan sederhana dengan metode DC ASPRIBUMI yang dirumuskan dengan bagan sebgaai berikut :
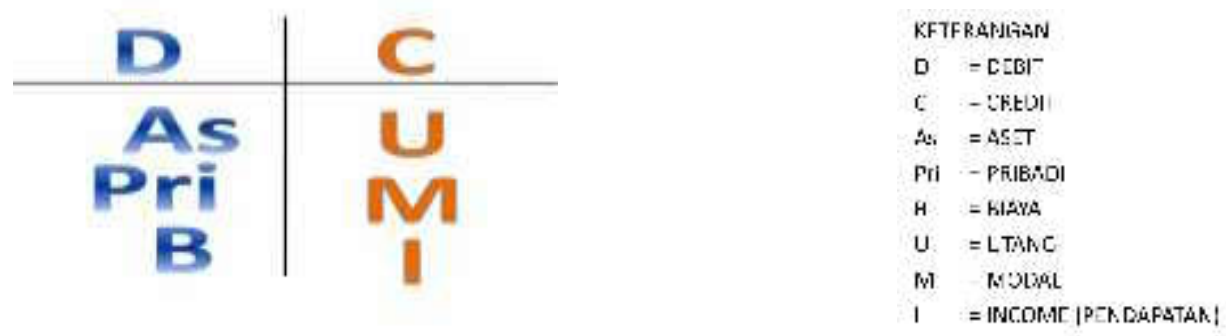

Laporan akuntansi yang menghasilkan informasi laba atau rugi disebut laporan keuangan. Laporan keuangan yang utama bagi perusahaan adalah laporan laba rugi, laporan ekuitas pemilik, neraca, dan laporan kas (Niswonger, 1991). Urutan penyusunannya adalah sebagai berikut : 
1. Laporan Laba Rugi : ikhtisar pendapatan dan beban dalam kurun waktu tertentu, sehingga dapat diperoleh informasi laba atau rugi yang dialami.

2. Neraca : suatu daftar aktiva, kewajiban, dan ekuitas pemilik pada tanggal tertentu, biasanya akhir bulan atau akhir tahun. Neraca berfungsi untuk mengetahui perkembangan usaha yang berjalan.

3. Laporan arus kas : ikhtisar untuk menilai kemampuan usaha dalam menghasilkan kas, setara kas, dan kebutuhan entitas dalam menggunakan arus kas tersebut selama periode waktu tertentu.

Berikut adalah contoh latihan pembuatan laporan keuangan dari proses pelatihan pembukuan sederhana.

\section{LAPORAN UNTUNG RUGI}

$\begin{array}{ll}\begin{array}{l}\text { INCOME/PENDAPATAN } \\ \text { PENJUALAN PRODUK }\end{array} & 800.000 \\ \text { BIAYA } & \\ \text { SEWA TOKO } & (500.000) \\ \text { UNTUNG / RUGI } & 300.000\end{array}$

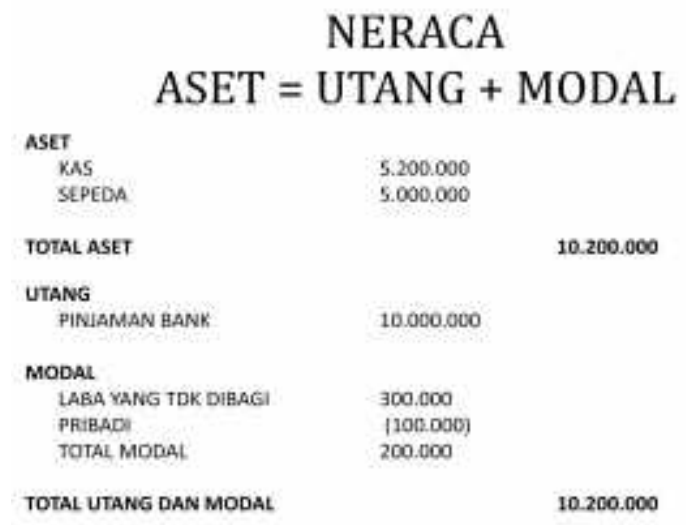

Kegiatan pengabdian kepada masyarakat tentang pembukuan sederhana diharapkan mampu meningkatan pengetahuan dan ketrampilan dilihat dari peningkatan kemampuan pengelola UMKM dalam membuat proses pembukuan dan peningkatan omzet penjualan dapat diketahui secara jelas.

\section{PENUTUP}

Berdasarkan hasil dan pembahasan kegiatan pengabdian kepada masyarakat yang telah diuraikan sebelumnya, dapat disimpulkan bahwa pemahaman peserta tentang pentingnya pembukuan semakin tinggi setelah mengikuti pelatihan pembukuan sederhana bagi UMKM dan kemampuan peserta pelatihan dalam pembukuan sederhana UMKM dapat meningkatkan akses permodalan usaha. Penyelenggaraan program pengabdian kepada masyarakat dengan bentuk penyelenggaraan pelatihan pembukuan sederhana sangat diperlukan dan diharapkan kegiatan seperti dapat dilakukan secara berkesinambungan. 


\section{Referensi}

Baas, T. dan M. Schrooten. 2006. Relationship Banking and SMEs: A Theoretical Analysis. Small Business Economics, 27.

Cziráky, D., S. Tiśma, and A. Pisarović. 2005. Determinant of Low Approval Rate In Croatia. Small Business Economic, 25, 347-372.

Pinasti, M. 2001. Penggunaan Informasi Akuntansi dalam Pengelolaan Usaha Para Pedagang Kecil di Pasar Tradisional Kabupaten Banyumas. Jurnal Ekonomi,Bisnis, dan Akuntansi, 1 (3). 